\title{
Comparison of The Gadoxetic Acid and Gadopentate Dimeglumine Efficiency for Determining Liver Metastases by an Enhanced MRI of Patients with Gastrointestinal Malignancies.
}

\author{
GiS Malignitesi Bulunan Hastaların Karaciğer \\ Metastazlarının MRG ile Görüntülenmesinde Gadoksetik \\ Asit ve Gadopentate Dimegluminin Etkinliğinin \\ Karşılaştırılarak Değerlendirilmesi
}

Cengiz Kadiyoran ${ }^{1}$,

Hilal Akay Cizmecioglu²,

Ahmet Cizmecioglu ${ }^{3}$,

Pinar Diydem Yilmaz ${ }^{4}$,

Necdet Poyraz ${ }^{1}$,

${ }^{1}$ Necmettin Erbakan University, Meram Faculty of Medicine, Division of Radiology, Konya

${ }^{2}$ Akademi Private Hospital, Division of Internal Medicine, Konya

${ }^{3}$ Farabi Private Hospital, Division of Internal Medicine, Konya

${ }^{4}$ Karatay University Medical Faculty,

Medicana Hospital, Division of Radiology. Konya

Geliş Tarihi/Received: 06 March 2018 Kabul Tarihi/Accepted: 09 May 2018

\begin{abstract}
Öz
Amaç: Bu çalışmanın amacı gastrointestinal sistem malignitesi bulunan hastaların karaciğer metastazlarının manyetik rezonans görüntüleme (MRG) ile görüntülenmesinde gadoksetik asit ve gadopentate dimegluminin etkinliğinin karşılaştırılarak değerlendirilmesidir

Hastalar ve Yöntem: Çalışmaya histopatolojik olarak gastrointestinal sistem malignitesi bulunan 50 hasta dahil edilerek bu hastalardaki karaciğer metastazları değerlendirilmiştir. Çalışmada etkinliğini araştırdığımız gadoksetik asit ve gadopentate dimeglumine ile elde edilen arteryel, portal, geç faz ve gadoksetik asite özel 20.dakikada elde edilen seriler karaciğer parankim kontrastlanması ve metastatik lezyon kontrastlanması açısından karşılaştırılmıştır.

Bulgular: Her iki kontrast madde için elde edilen serilerde; gadoksetik asit uygulanan hastalarda 20. dakikada elde edilen seriler ile gadopentate dimeglumine uygulanmasını takiben geç fazda elde edilen seriler karaciğer parankiminin ve metastatik lezyonun intensitesi açısından karşılaştırıldığında gadoksetik asit lehine anlamlı fark tespit edilmiştir $(p<0,05)$. Her iki kontrast madde ile elde edilen serilerde arteryel, portal ve geç faz serilerde ise karaciğer parankiminin ve metastatik lezyonun intensitesi açısından anlaml fark tespit edilememiştir $(p>0.05)$. Gadoksetik asit uygulamasını takiben arteryel, portal, geç fazda ve 20. dakika serilerde karaciğer parankim intensitesinde fazlar süresince istatistiksel anlamlı kontrastlanma artışına yol açmaktadır $(p<0.05)$. Bu süre zarfında metastatik lezyonlarda ise anlamlı intensite artışı mevcut değildir $(p>0.05)$.

Sonuc: Gadoksetik asit hepatoselüler bir kontrast madde olup gastrointestinal sistem maligniteli hastaların karaciğer metastazlarının manyetik rezonans ile değerlendirilmesinde önemli tanısal katkılar sağlar. Özellikle gadoksetik asit ile 20. dakikada elde edilen serilerde karaciğer kontrastlanması artarken metastatik lezyonlardaki kontrastlanmanın artmıyor olması karaciğerdeki metastatik lezyon ve norma karaciğer parankimi arasında belirgin kontrast farkına yol açmaktadır
\end{abstract}

Anahtar Kelimeler: Gadoksetik asit, gadopentate dimeglumine, karaciğer metastazı.

\begin{abstract}
Aim: The aim of this study was to evaluate the efficacy of gadoxetic acid and gadopentate dimeglumine in the evaluation of liver metastases of patients with gastrointestinal malignancy by magnetic resonance. Patients and Methods: A total of 50 patients were diagnosed gastrointestinal malignancies histopathologically were included in the study and their hepatic metastases were examined by magnetic resonance for gadoxetic acid and gadopentate dimeglumine. Arterial, portal and late phase images obtained for these contrast agent and also 20th minutes images obtained for gadoxetic acid.

Results: There was statistically significant difference between the series obtained at the 20th minutes after administration of gadoxetic acid and late phase with gadopentate dimeglumine for hepatic parenchymal and metastatic lesion intensity $(p<0.05)$. We found no statistically significant difference for these contras agent at arterial, portal and late phase series $(p>0.05)$. After the administration of gadoxetic acid, arterial, portal, late phase and the 20th minute series intensity of hepatic enhancement significantly reduced. At this time there was not a significant enhancement of the metastatic lesions. $(p>0.05)$

Conclusion: Gadoxetic acid, a hepatoceluler contrast agent, have important diagnostic contribution to the assessment of the patients with liver metastases of gastrointestinal malignancies by magnetic resonance imaging. When the hepatic parenchymal enhancement increased and the enhancement of metastatic lesions reduced, thus the enhancement difference between normally hepatic parenchyma and metastatic lesions might help the detection of the lesions especially in the 20th minute series.
\end{abstract}

Key words: Gadoxetic acid, gadopentate dimeglumine, hepatic metastase.

Address correspondence to: Cengiz Kadiyoran, Necmettin Erbakan University, Meram Faculty of Medicine, Division of Radiology, Konya, Turkey

e-mail: ckadiyoran@hotmail.com

Cite this article as: Kadiyoran C, Cizmecioglu HA, Cizmecioglu A, Yimaz PD, Poyraz N. Comparison of the gadoxetic acid and gadopentate dimeglumine efficiency for determining liver metastases by an enhanced MRI of patients with gastrointestinal malignancies. Selcuk Med J 2018;34(4): 148-154

Disclosure: None of the authors has a financial interest in any of the products, devices, or drugs mentioned in this article. The research was (to full access to the primary data and to allow the journal to review the data if requested. 


\section{INTRODUCTION}

$20 \%$ of patients with gastrointestinal system carcinomas have liver metastases at diagnosis time. In autopsy series, hepatic metastases are present in almost half of patients with GIS (gastrointestinal system) cancer. Radiologic imaging is very useful to determine metastasis presence and evaluate the chemotheraphy response (1).

The advantages of magnetic resonance imaging (MRI) are superior to other radiological imaging modalities because of the absence of harmful ionizing radiation, multiple planar imaging, and vascular network detection (2). The detection and characterization of the metastatic lesion in the liver parenchyma affect the treatment and prognosis of the disease. Contrast-enhanced MRI plays an important role in this situation, especially in the small lesions.

The schematic view of the liver lesions before (Figure 1a) and after (Figure 1b) contrast agent administration is shown below.

One of the contrast agent in our study "Gadopentate dimeglumine (Gd-BOPTA)" is an extracellular contrast agent used in central nervous system and liver imaging, whereas the other one "gadoxetic acid (Gd-EOB-DTPA)" is a liver specific contrast agent $(3,4,5)$. In this way, early and definitive diagnosis of liver metastases significantly affects the success of both surgeon and ablation therapy.

The aim of this study is to compare the gadoxetic acid and gadopentate dimeglumine efficiency for determining liver metastases by an enhanced MRI of patients

\section{PATIENTS AND METHODS}

Before the study was initiated, the consent of Selçuk University, Meram Medical Faculty of Medicine's Board of Ethics for Clinical Trials was obtained (2009-399). All patients participating in the study were informed in detail about the study and then their written consent was taken and the patients

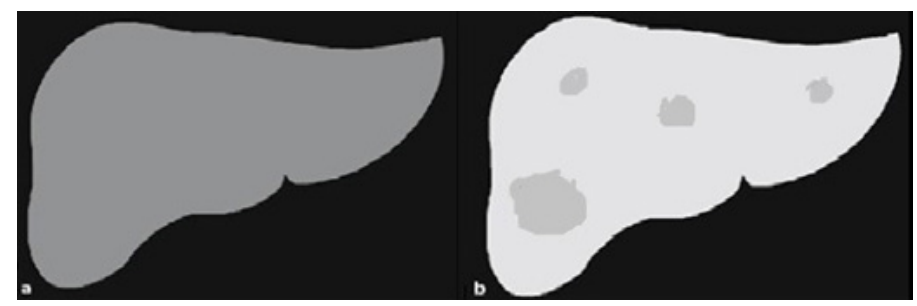

Figure 1. Schematic view of the liver lesions; before (a) and after (b) contrast agent administration. New lesions detection after contrast administration.

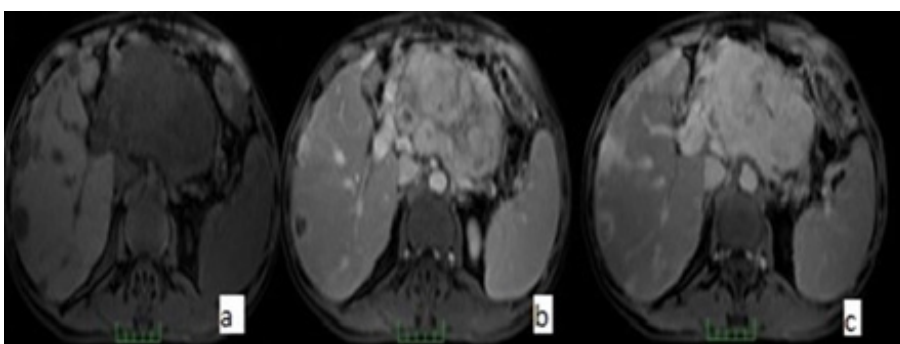

Figure 2. Dynamic images of arterial, portal and late phase $(a, b, c)$ images after gadopentate dimeglumine administration to a 50 years old patient with pancreas cancer.

were included in the study.

During the evaluation, all of the patient images were processed by the same standard window settings found in the PACS program. Furthermore, intensities from both the liver parenchyma and metastatic lesions without hepatic necrotic areas in both arterial portal and late phase dynamically obtained for both contrast agents were recorded with the help of region of interest (ROI).

\section{Patient population:}

The prospective study included 50 patients having gastrointestinal system (pancreas, stomach, colorectal, small bowel) malignancies which were histopathologically confirmed and liver metastases were shown on previously taken CT and MRI examinations. A total of 25 patients who had been taking gadoxetic acid and gadopentate dimeglumine were included in the study for researching their efficacy with dynamic liver MRI.

All patients have been informed and approved about the procedure. Patients with poor vital situations, not able to holding breath, not allowed to enter the MRI device (heart pacemaker, claustrophobic patient), urea and creatinine abnormalities were excluded from the study. Patients were evaluated for renal functions before liver MRI, and attention was shown for the values are within normal limits. Thus, patients with

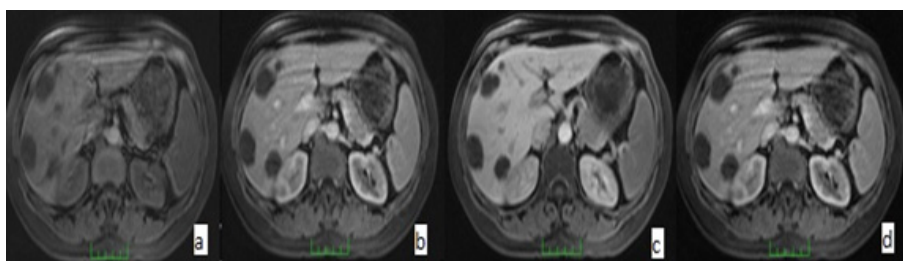

Figure 3. Dynamic images of arterial, portal, late phase and 20th minute (a, b, c, d) images after administration of gadoxetic acid to a 48 years old woman with colorectal cancer. 


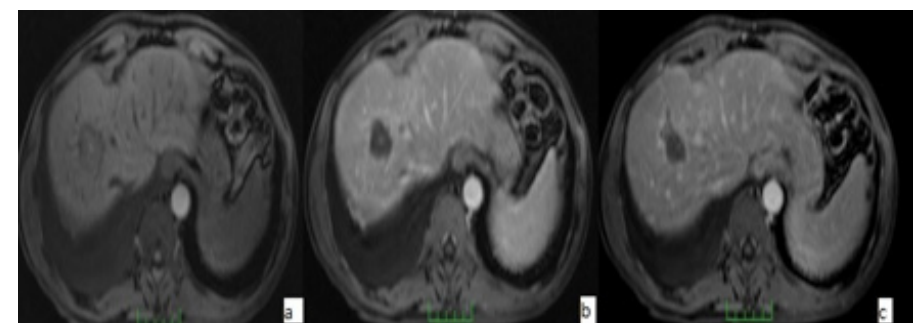

Figure 4. Dynamic images of arterial, portal, late phase (a, b, c, ) after administration of gadopentate dimeglumine to a 59 years old man with colon cancer.

borderline and high urea and creatine levels were not included to the study.

\section{Imaging protocols:}

All patients urea and creatinine values and vital findings were checked before MRI and previous and post-contrast series were obtained with Siemens Magnetom Symphony 1.5 Tesla MRI device. MRI was performed using standard flexible body coils by the supine position, with the following protocol and standard imaging parameters, respectively. Contrast agent was applied at the rate of $2 \mathrm{ml} / \mathrm{min}$ by the access of V.brachialis on the left antecubital region. T2 TRUFI coronal, FLASH 3D fat-saturated, T2 axial, T1 FLASH $2 \mathrm{D}$ in and opposed phase sequences were taken from both gadoxetic acid and gadopentate dimeglumine groups. Also late phase series were added to the group of gadopentate dimeglumine, and 20th minute series were added to the group of gadoxetic acid. Arterial, portal and late phase series of liver were obtained dynamically from the MRI study.

Image evaluation:

After all images obtained for two contrast agents, the images were evaluated by a radiologist who does not know which contrast agent was used. The physical conditions of the report rooms are kept equal to ensure optimal assessment. The standard windows settings were used for all patients images.

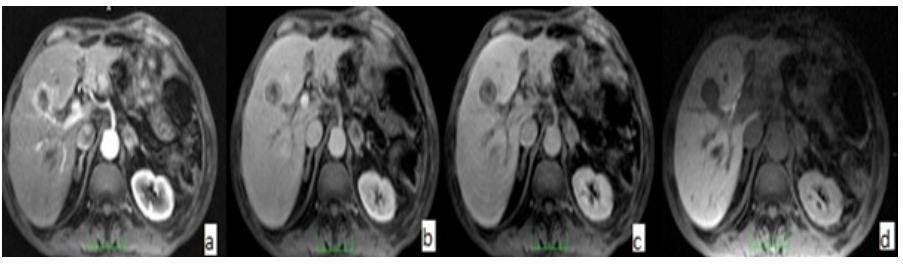

Figure 5. Dynamic images of arterial, portal, late phase and 20th minute $(a, b, c, d)$ images after administration of gadoxetic acid to a 57 years old man with pancreas cancer.
In the current series, liver parenchyma and metastatic lesion intensities were measured for arterial, portal, late phase and 20th minute value of gadoxetic acid for both contrast agent groups. In both groups, intensities of three different parenchyma fields in which vascular structures and metastatic lesions were not observed around the portal phase were measured with the help of standart sized ROI and the averages of them were notted. Similar to the previous sampling at the same region, both arterial, portal and late phases, intensities were measured from the parenchyma area where the vascular structure and metastatic lesions were not observed in the liver parenchyma. Also measurements from metastatic lesions without any necrotic areas in all three phases were recorded at the same region by $\mathrm{ROI}$. The series obtained from the late phase of gadopentate and 20th minute of gadoxetic acid were compared in terms of liver parenchyma and metastatic lesion intensities.

In the gadoxetic acid group, the intensities that were measured earlier in arterial, portal, late phase, and 20th minute series were compared with the intensities of the liver parenchyma and metastatic lesions to assess the change in intensity as the sequences progressed. Metastatic lesions on portal phase were compared with the series on the 20th minute, in order to evaluate the contribution of the 20th minute series to the detection of new metastases in the gadoxetic acid series, thus the new detected lesions were noted.

\section{RESULTS}

A total of 25 patients with gastrointestinal malignancies were evaluated for determining liver metastasis by dynamic liver MRI examinations with the gadoxetic acid and gadopentate dimeglumine.

The ages of the patients ranged from 42 to 72 years and the mean age was $58.8 \pm 7.8$. Twenty-five patients with hepatic metastasis were included in the "gadopentate dimeglumine" group (Figure 2 and 4). In this group, the ages of the patients ranged from 34 to 84 and the mean age was $58.8 \pm 10.6$. The gadoxetic acid was composed of 5 female. A total of $48 \%$ of them had colorectal carcinoma, $36 \%$ of them had stomach cancer and $16 \%$ of them had pancreatic cancer (Figure 3 and 5). In the gadopentate dimeglumine group, 6 of them were female. And a total $64 \%$ of them had colorectal carcinoma, $20 \%$ of them had pancreatic cancer, $25 \%$ of them had stomach cancer and the remaining $4 \%$ had small bowel cancer.

The mean values which was taken three times from the liver parenchyma site where there was no vascular 
Table 1. Liver parenchyma and metastatic lesion intensities at arterial, portal, late phase for both contrast agent and 20th minute intensities for gadoxetic acid.

\begin{tabular}{|c|c|c|c|c|}
\hline \multirow[b]{2}{*}{ MRI phase } & \multicolumn{2}{|c|}{$\begin{array}{l}\text { MRI intensity of parenchyma } \\
\text { (mean value } \pm \text { SD) }\end{array}$} & \multicolumn{2}{|c|}{$\begin{array}{l}\text { MRI intensity of metastasis } \\
\text { (mean value } \pm \text { SD) }\end{array}$} \\
\hline & gadoxetic acid & gadopentate dimeglumine & gadoxetic acid & gadopentate dimeglumine \\
\hline Arterial phase & $170.52 \pm 38.25$ & $189.76 \pm 57.10$ & $109.52 \pm 57.82$ & $121.16 \pm 61.35$ \\
\hline Portal phase & $220.60 \pm 65.19$ & $227.00 \pm 67.48$ & $103.84 \pm 49.47$ & $125.0 \pm 61.43$ \\
\hline Late phase & $218.48 \pm 64.97$ & $204.52 \pm 63.79$ & $115.00 \pm 44.97$ & $126.44 \pm 70.24$ \\
\hline 20th minute & $230.56 \pm 76.49$ & --- & $102.04 \pm 47.01$ & --- \\
\hline
\end{tabular}

structures and metastatic lesions in the vicinity at the arterial, portal and late phases with the help of ROI were compared for both groups. The mean intensities of the liver parenchyma in the gadoxetic acid group and in the gadopentate dimeglumine group, notted respectively (Table 1 ). There was no statistically significant difference between these two values.

Intensity measurements performed with the help of ROI from the central part of metastatic lesion that does not contain necrotic areas in both the liver parenchyma and the liver in the dynamically obtained arterial, portal and late phases were compared to each other in three phases. There was no statistically significant difference between the two groups in the intensities obtained in the arterial, portal and late phases compared to the two drug groups ( $p>0.05)$. These values are summarized in table 1 . There was no significant difference in intensities between arterial, portal and late phase groups for each contrast agent $(p>0.05)$.

However, statistically significant differences were found in favor of gadoxetic acid in comprasion with the late series obtained with gadopentate dimeglumine in terms of liver parenchyma and metastatic lesion intensities at the 20th minute obtained with gadoxetic acid $(p<0.05)$. These values are summarized in the table 1.

The value of the paranchyme intensities obtained with gadoxetic acid at the 20th minute and in the gadopentate dimeglumine group summarized at the table 1. This difference between the two groups was statistically significant in favor of gadoxetic acid ( $p$ $<0.05$ ). The normal parenchymal staining of the liver with gadoxetic acid at the 20th minute is significantly different from gadopentate dimeglumine administered group at late series.

The results were statistically significant when the intensities of metastatic lesions were compared. The arterial, portal, late phase, and 20th minute series of gadoxetic acid administration were compared in terms of both liver parenchymal and metastatic lesion intensities. The liver parenchyma intensity was starting to increase from the arterial phase to 20th minute series. The measured intensities summarized at the table 1.

There was no significant enhancement from the portal to the late phase in the parenchymal intensities. However, there was a statistically significant increase in the liver parenchyma intensities compared to the previous phases in the series obtained at 20th minute $(p<0.05)$. Intensity values for evaluating liver parenchymal enhancement following gadoxetic acid administration are summarized in table 1 for all phases.

According to these values, it is understood that the liver parenchyma intensities get increase during the phases. As the phases progress, liver parenchyma enhancement increases as the intensity measurements are taken into consideration. The intensities of the metastatic liver lesions were also compared for all phases. There was no statistically significant difference in the intensities of metastatic lesions between the phases (arterial, portal, late) and 20th minute series ( $p>0.05)$. Intensity values of metastatic lesions were summarized in the table 1.

When the portal phase and the 20th minute series were counted to evaluate the contribution of gadoxetic acid in the hepatic metastasis, there was no change in the number of metastatic lesions at the portal phase and at the 20th minute series. Thus the hepatospecific phase does not have a superiority to portal phase in terms of new lesion detection.

\section{DISCUSSION}

In our study, mean liver parenchyma intensities were found as $230.56 \pm 76.49$ in the series obtained at 20th minute with gadoxetic acid and mean values of liver parenchyma intensities in late phase were $204.52 \pm 63.79$ in the patients receiving gadopentate dimeglumine. This difference between the two groups was statistically significant. The normal parenchymal staining of the liver with gadoxetic acid is significantly 
different from gadopentate dimeglumine at the 5th minute series obtained and gadoxetic acid at 20th minute. Thus, it is easier to distinguish the metastatic lesion from the normal liver parenchyma while the liver enhancement is getting increases. The mean intensities of metastases stained with gadoxetic acid were measured as $102.04 \pm 47.01$ and the intensity of the metastatic lesion stained with gadopentate dimeglumine was measured as $126.44 \pm 70.24$ when the intensity values measured from the metastatic lesions were compared with the series obtained at the 20th minute. When 20th minute series compared metastatic lesions showed fewer contrast with gadoxetic acid. There was also statistically significant difference between these values $(p<0.05)$.

There are few studies in the literature comparing two contrast agents about the liver MRI imaging. Huppertz et al. (6) mentioned about the efficacy of gadoxetic acid in the characterization and classification of focal liver lesions in liver MRI. MRI studies by Stern et al. (7) performed a study with different doses of gadoxetic acid and found the agent did not cause pain, discomfort at the injection site. Also, there was no difference in vital findings, clinical laboratory tests, urine analysis in these doses.

Brismar et al. (8) conducted a study of healthy volunteers using gadopentate dimeglumine and gadoxetic acid to compare two contrast media for assessment of liver vascular structures. Vascular signal intensities were compared at hepatic artery, portal and middle hepatic vein and gadopentate dimeglumine have more contrast enhancement in arterial, portal and late phases compared to gadoxetic acid. But, it was noted that there was no significant difference in the staining of liver parenchym for both contrast media.

A study performed by Vogl et al. (9), the superiority of gadoxetic acid and gadopentate dimegluminin in the detection of focal liver lesions was investigated. In the study, MR images were obtained by applying gadoxetic acid at different doses of 12.5, 25 and 50 $\mu \mathrm{mol} / \mathrm{kg}$, respectively, and gadopentate dimeglumine at a dose of $0.1 \mu \mathrm{mol} / \mathrm{kg}$ in the following week to the same patient group with focal liver lesion. Gadoxetic acid was emphasized in lesion detection compared to gadopentate dimeglumine, especially in small lesions at the hepatobiliary phase. Also, the superiority of gadoxetic acid to gadopentate dimeglumine and detection of metastasis in non-contrasted series was mentioned in patients with liver metastases. In our study, we investigated the differences in the number of metastatic lesions by comparing portal and 20th minute series of patients who received gadoxetic acid, and found there was no difference in these two phases.

Hammerstingl et al. (10) concluded that gadoxetic acid was more successful than gadopentate dimeglumine in detecting the lesions in the liver, and this achievement was highlighted the importance of comparability at high doses.

In the study performed by Filippone et al. (11) arterial, portal and late phase series were taken following gadobenate dimeglumine and gadoxetic acid administration in patients with suspicious liver lesions. Individuals were enrolled at 20th and 40th minutes after taking gadoxetic acid gadobenate dimeglumine, respectively. It was reported that Gadoxetic acid is superior to gadobenate dimeglumine in hepatospecific phase.

Vogl et al. (9) reported a significant increase till the hepatobiliary phase in the liver intensities after contrast agent administration in the study of contrast enhancement of normal liver parenchyma following gadoxetic acid administration. Those findings are correlated with our current study.

In the study performed by Stern et al. (7) the dynamic contrast enhancement obtained with 3 different doses of gadoxetic acid was used to obtain a series up to 10th minute. It has been reported that liver parenchymal enhancement increases within the time period up to 10th minutes with every 3 doses. The results were statistically significant such as our study.

Due to metastatic liver lesions destroy hepatocytes, they are always hypointense after contrast administration. The liver-specific contrast material increases the incidence of metastatic lesion detection by prominently staining the liver parenchyma adjacent to the lesion (5).

Because of gadoxetic acid is a hepatocellular agent, it is selectively retained by the liver kuppfer cells. The enhancement of gadoxetic acid in the hepatic parenchyma in which kuppfer cells are much more is greater than gadopentate dimeglumine (12). Thus, it is easier to detect a metastatic lesion due to the more contrast enhancement of liver parenchyma and less staining metastatic lesion in contrast. Furthermore, as the sequences progress, parenchymal enhancement increases in intensity values in patients treated with gadoxetic acid. Liver parenchymal enhancement is most apparent at the 20th minute.

In our study; we concluded that there was no 
superiority in arterial, portal and late phases in terms of liver intensities when gadoxetic acid was compared with gadopentate dimeglumine in the detection of liver metastases. And we also concluded that gadoxetic acid had statistically significant contributions to liver intensities compared to the late phase series obtained with gadopentate dimeglumine at the 20th minute series.

We detected the superiority of gadoxetic acid to gadopentate dimeglumine in evaluating hepatic parenchyma intensities. We observed that when the gadoxetic acid-applied patients were compared with the portal phase and the 20th minute series, there could be no new metastatic lesions according to the portal phase in the 20th minute series.

Metastatic lesions do not contain kuppfer cells or less from liver paranchym. Thus the contrast enhancement of the metastatic lesion with gadoxetic acid is less than gadopentate dimeglumine which is an extracellular contrast agent. And the enhancement of normal hepatic parenchyma with gadoxetic acid is greater than gadopentate dimeglumine does. Because of this contrast advantage, it is more easier to detect metastatic lesions in the liver. Parenchymal enhancement of the patients who has taken gadoxetic acid increases in terms of intensities as the sequences progress. When the parenchymal enhancement was evaluated by the intensities during the examination period, the most significant parenchymal enhancement was observed in the 20th minute series of gadoxetic acid specimens.

Patients with chronic renal disease had not been included to the study. However, the study of patients with moderate or severe renal insufficiency showed no systemic fibrosis progression over a retrospective 2-year period (13). Dyspnea, one of the most common side effects following administration of contrast media, is lower during the administration of gadoxetic acid (14).

\section{CONCLUSION}

Gastrointestinal system cancers are one of the major health problems. End organ metastases affect the surveillance and treatment in patients with malignancies. Contrast enhanced MR examination also plays an important role in the diagnosis of liver metastases.

After the administration of gadoxetic acid, liver parenchyma intensities increased gradually from arterial to the 20th minute. When the images obtained with gadoxetic acid (20th minute) is superior to gadopentate dimeglumine (late phase) in terms of both enhancement of liver parenchyma and detection of metastatic lesions

In conclusion, gadoxetic acid is a hepatospecific gadolinium chelate and contributes to the dynamic examination of the liver like detection, characterization of metastatic lesions.

Conflict of interest: Authors declare that there is no conflict of interest between the authors of the article.

Financial conflict of interest: Authors declare that they did not receive any financial support in this study.

Address correspondence to: Cengiz Kadıyoran, Yunus Emre Mah. Necmettin Erbakan University, Meram Faculty of Medicine, Division of Radiology, 42080 Meram/Konya

Telephone: +90 3322236337 e-mail: ckadiyoran@hotmail.com

\section{REFERENCES}

1. Schima W, Kulinna C, Langenberger $H$, et al. Liver metastases of colorectal cancer: US, CT or MR? Cancer Imaging 2005;5:149-56.

2. Kim YK, Park G, Kim CS, et al. Diagnostic ef cacy of gadoxetic acid-enhanced MRI for the detection and characterisation of liver metastases: Comparison with multidetector-row CT. Br J Radiol 2012;85:539-47.

3. Guo Y, Li W, Cai W, et al. Diagnostic value of gadoxetic acidenhanced MR imaging to distinguish HCA and its subtype from FNH: A systematic review. Int J Med Sci 2017;14:66874.

4. Bellin MF. MR contrast agents, the old and the new. Eur $\mathrm{J}$ of Radiol 2006;60:314-23.

5. Tsurusaki M, Sofue K, Murakami T. Current evidence for the diagnostic value of gadoxetic acid-enhanced magnetic resonance imaging for liver metastasis. Hepatol Res 2016;46:853-61.

6. Huppertz A, Balzer T, Blakeborough A, et al. Improved detection of focal liver lesions at MR imaging: Multicenter comparison of Gadoxetic Acid-enhanced MR images with intraoperative findings. Radiol 2004;230:266-75.

7. Stern W, Schichk F, Kopp AF, et al. Dynamic MR imaging of liver metastases with Gd-EOB-DTPA. Acta Radiol 2000;41:255-62.

8. Brismar TB, Dahlström N, Edsborg N,et al. Liver vessel enhancement by Gd-BOPTA and Gd-EOB-DTPA: A comparison in healthy volunteers. Acta Radiol 2009;50:70915.

9. Voggel T, Kummel S, Hammmerstingl R, et al. Liver tumours: Comparison of MR imaging with Gd-EOB-DTPA and GdDTPA. Radiology 1996;200:59-67.

10. Hammerstingl R, Zangos S, Schwarz W, et al. Contrastenhanced MRI of focal liver tumors, Using a hepatobiliary MR contrast: Detection and differential diagnosis using GdEOB-DTPA-enhanced versus Gd-DTPA-enhanced MRI in the same patient. Acad Radiol 2002;9:119-20.

11. Filippone A, Blakeborough A, Breuer J, et al. Enhancement of liver parenchyma after injection of hepatocyte-spesific MRI contrast media: A comparison of gadoxetic acid and gadobenate dimeglumine. J Magn Reson Imaging 
2010;31:356-64

12. Lee $\mathrm{KH}$, Lee JM, Park JH, et al. MR imaging in patients with suspected liver metastases: Value of liver-specific contrast agent gadoxetic acid. Korean J Radiol 2013;14:894-904.

13. Lauenstein T, Ramirez-Garrido F, Kim YH, et al. Nephrogenic systemic fibrosis risk after liver magnetic resonance imaging with gadoxetate disodium in patients with moderate to severe renal impairment: Results of a prospective, open-label, multicenter study. Invest Radiol 2015;50:416-22.
14. Endrikat J, Kim SY, Sakaguchi T, et al. Safety of gadoxetate disodium: Results from six clinical phase IV studies in 8194 patients. Acta Radiol 2016;57:1326-33. 